\title{
Islet transplantation
}

National Diabetes Information Clearinghouse (NDIC)

\section{Definitions}

Islets

Defined by National Diabetes Information Clearinghouse (NDIC)

Pancreas

Defined by National Diabetes Information Clearinghouse (NDIC)

Insulin

Defined by National Diabetes Information Clearinghouse (NDIC)

Beta cell

Defined by National Diabetes Information Clearinghouse (NDIC)

Blood glucose

Defined by National Diabetes Information Clearinghouse (NDIC)

\section{Source}

National Diabetes Information Clearinghouse (U.S.). (2009). The diabetes dictionary. [Bethesda, Md.]: U.S. Dept. of Health and Human Services, National Institutes of Health, National Institute of Diabetes and Digestive and Kidney Diseases,

National Diabetes Information Clearinghouse.

Moving the islets from a donor pancreas into a person whose pancreas has stopped producing insulin. Beta cells in the islets make the insulin that the body needs for using blood glucose. 